\title{
Effect of Biosynthesized Zinc Oxide Green Nanoparticles on Pulse Beetle, Callosobruchus analis (Coleoptera: Chrysomelidae)
}

\author{
Wazid $^{1 *}$, Sushila Nadagouda ${ }^{1}$, A. Prabhuraj ${ }^{1}$, R. Harishchanra Naik ${ }^{1}$, \\ N.M. Shakuntala ${ }^{2}$ and H. Sharanagouda ${ }^{3}$ \\ ${ }^{1}$ Department of Agricultural Entomology, College of Agriculture, UAS, Raichur, \\ Karnataka, India \\ ${ }^{2}$ Department of Seed Technology, College of Agriculture, UAS, Raichur, Karnataka, India \\ ${ }^{3}$ Department of Processing and Food Engineering, CAE, UAS, Raichur, Karnataka, India \\ *Corresponding author
}

\begin{abstract}
A B S T R A C T
Among the stored product insects, Callosobruhus analis (Fabricius) is a cosmopolitan and serious pest of pulses in field as well as in storage condition. The excessive use of pesticides and chemical compounds led to development of resistance, resurgence and has

Keywords

Callosobruhus analis,

Zinc oxide

nanoparticles, Chick

pea, Mortality

Article Info

Accepted:

06 August 2018

Available Online:

10 September 2018 an adverse effect on environment. This experiment was conducted at Centre for Nanotechnology Laboratory, UAS, Raichur. In the recent years, nanotechnology has emerged as a promising tool for pest control. In the present study, we reported the biological synthesis of zinc oxide green nanoparticles from spinach leaves. The green synthesized zinc oxide nanoparticles were characterized by UV-Vis spectroscopy, X-ray diffraction (XRD), Zetasizer and Scanning electron microscope (SEM). The bio-physical characterization revealed that the zinc oxide nanoparticle has a hexagonal structure with a mean particle size of $20.67 \mathrm{~nm}$. The pesticidal effects of Zinc oxide green nanoparticles $(\mathrm{ZnO})$ were used as stored product insect protectants compared to chemical malathion as standard reference. Data obtained from different concentration $(250,500,750,1000,1250$ and $1500 \mathrm{ppm}$ ) of zinc oxide green nanoparticles indicated that the increasing of concentration and exposure period caused increasing in adult mortality (\%). Among the different concentration $1500 \mathrm{ppm}$ of zinc oxide nanoparticle proved to be superior by recording highest mortality, lowest number of eggs, least seed damage, and seed weight loss in chick pea seeds up to one month of storage.
\end{abstract}

\section{Introduction}

Stored grains are ravaged by a number of insect pests. The stored grain pests infest grains to fulfill their food and shelter requirements resulting in qualitative as well as quantitative losses. The tropical climate of India is highly favourable for continuous occurrence of storage insect pests throughout the year. A number of insect pests gain access to the grain storage at various stages of processing of food grains/ seeds viz., during the process of development and maturation of seeds/ grains, processing in threshing yards, during transit or while in storage. Some insect pests initiate damage at the ripening stage of 
crops and continue during storage. Major sources of infestations are old bags, storage structure, old containers, and cross over infestation (Chitra and Subramanian, 2016).

Callosobruchus analis is a very important pest of grain legumes both in storage and field. It is distributed throughout India. It attacks peas, chickpea, pigeon pea, black gram, horse gram, cowpea etc. Larva which grows inside eats endosperm, and then the seed is totally damaged. Adults are non-feeding. Cross infestation is very common, as adults are capable of flying. It causes $33 \%$ infestation to legume seeds. Larval feeding on the cotyledons causes significant losses in seed weight and viability. Gujar and Yadav (1978) reported 55- 60\% losses in seed weight and 45.5 to $66.3 \%$ losses in protein content due to bruchid infestation in storage and the infested seeds become unfit for human consumption.

Nanotechnology has revolutionized the world with tremendous advancements in many fields of science like engineering, biotechnology, analytical chemistry and agriculture. Their use in crop protection is just in its infancy (Resham et al., 2015). Nanomaterials measure between approximately 1 and $100 \mathrm{~nm}$. Over many decades, nanotechnology and nanomaterials have been employed successfully and safely in various fields like medicine, environmental science and food processing. However, the use of nanomaterials in agriculture, especially for plant protection and production, it is an under-explored research area (Khot et al., 2012). It has been used as conductors and semi-conductors, medical devices, sensors, coatings, catalytic agents and also as pesticides (Jordan, 2010).

Nanoparticles have large surface to volume ratio, chemically alterable physical properties, and possess strong affinity to targets such as proteins (Kumar et al., 2010). Nano biosensors and other field sensing devices can be used in detection and measurement of crop nutrient status, detection of hidden infestation of storage insects, pathogens, weeds, moisture level, soil fertility, temperature, etc. which helps in real time monitoring of the crop growth and provide essential data for precision farming practices leading to minimize agricultural inputs and maximizing resource output and yield (Scott and Chen, 2003).

\section{Materials and Methods}

The spinach leaves (Spinacia oleracea) (Heena variety) were collected from University campus and chickpea seeds (JG11) were collected from seed unit, UAS, Raichur and Zinc nitrate hexahydrate $\left[\mathrm{Zn}\left(\mathrm{NO}_{3}\right)_{2} \cdot 6 \mathrm{H}_{2} \mathrm{O}\right]$ was procured from $\mathrm{M} / \mathrm{s}$. High Media, Bangalore.

\section{Biosynthesis of Zinc oxide green nanoparticles from spinach leaves}

The leaf extract of spinach $(50 \mathrm{ml})$ was boiled at $60-80{ }^{0} \mathrm{C}$ using magnetic stirrer. Zinc nitrate hexa hydrate $\left[\mathrm{Zn}\left(\mathrm{NO}_{3}\right)_{2} \cdot 6 \mathrm{H}_{2} \mathrm{O}\right]$ was used as a precursor. $1 \mathrm{mM}$ Zinc nitrate solution was prepared using distilled water. The solution was added to the leaf extract when temperature reached to $60^{\circ} \mathrm{C}$ and boiled for $30 \mathrm{~min}$ or until colour changed. A change in the colour from dark green to pale yellow indicates the formation of Zinc oxide nanoparticles (Amrita et al., 2015).

Zinc oxide green nanoparticles were confirmed by UV-Visible spectrophotometer (Perkin Elmer, Lamda 35, Germany) in 350 $410 \mathrm{~nm}$ wavelength range.

The size and morphology of the synthesized Zinc oxide nanoparticles was characterized by Zetasizer (Malvern, ZETA Sizer, nano383 issue 5.0, England) X-ray diffraction and scanning electron microscope (Carl Zeiss Microscopy, EVO 10, Germany). 
Maintenance of pure culture of pulse beetle on chick pea seeds

Pulse beetle was collected from the infested chick pea seeds and the culture was further maintained in plastic jars of two kg capacity containing chickpea seeds (JG-11). The plastic jars were covered with muslin cloth and fastened tightly with the help of rubber band. Fresh seeds were provided regularly and exposed separately for the multiplication of insects at room temperature of $27^{\circ} \mathrm{C}$. The insects emerged from this culture were used throughout the period of experimentation.

\section{Preparation of green nanoparticle solutions}

The zinc oxide green nanoparticle which synthesized from spinach leaves was obtained from Centre for Nanotechnology laboratory, University of Agricultural Sciences, Raichur for the present study.

Bioassay studies for pulse beetle on chickpea seeds

Effects of biosynthesized zinc oxide green nanoparticles on adults of $C$. analis were determined by contact toxicity assay at seven doses of 125, 250, 500, 750, 1000, 1250 and $1500 \mathrm{ppm}$ of nanoparticle kg-1 chickpea seeds. The experiments were carried out in Completely Randomized Design with three replications each consisted of 20 adults of $C$. analis in small plastic screw capped jars containing $100 \mathrm{~g}$ of chickpea seeds in each jar were treated individually with nanoparticles and the plastic box were closed with muslin cloth and fastened tightly with the help of rubber band. Then, the jars were shaken manually for approximately 60 seconds to achieve equal distribution of nanoparticles on chickpea seeds. In one additional set no nanoparticle was mixed with chickpea seeds and this set served as control. After that 20 unmated adults of $C$. analis were introduced into each jar. All bioassays were performed at $30 \pm 1 \mathrm{oC}$ and $65 \pm 5 \% \mathrm{RH}$. Insect mortality was checked after 1, 3, 5, 7 and 10 days after treatment. The observation were also recorded 1 month after treatment on number of eggs laid per 100 seeds, number of adults emerged per $100 \mathrm{~g}$ of seeds, per cent seed damage, per cent weight loss, germination per cent, Dehydrogenase enzyme activity and percent reduction over control.

\section{Results and Discussion}

The size reduction of Zinc ions into zinc oxide nanoparticles were observed as the colour changed from dark green to pale yellow. The sharp bands of zinc oxide nanoparticles were observed around $375.4 \mathrm{~nm}$ as shown in figure 1 and similar results were obtained by (Awwad et al., 2016) with $374 \mathrm{~nm}$ and (Singh et al., 2015) with $368 \mathrm{~nm}$.

The average particle diameter (Zetasizer) zinc oxide nanoparticle was found to be $20.67 \mathrm{~nm}$ as shown in figure 2. (Sindhura et al., 2015) obtained $53 \mathrm{~nm}$ and (Supraja et al., 2015) obtained $20.3 \mathrm{~nm}$ for $\mathrm{ZnO}$ NPs. The morphological features of zinc nanoparticles were characterized by scanning electron microscope and observed to be spindle shape. Similar results were also reported by (Noorjahan et al., 2015) for ZnO NPs.

\section{Mortality of pulse beetle}

In the present investigations, the effect of Zinc oxide nanoparticles was tested on mortality of pulse beetles at different concentrations. It was observed that with increase in concentrations and number of days after treatment, the mortality also increased. Green zinc oxide nanoparticle @ 1500ppm proved to be superior by recording highest mortality of $40.00,76.66,83.33,93.33$ per cent, on 1,3,5,7 and 10 days after treatment and it was on par with its lower dosage @ 1250ppm where in 
mortality ranged from 36.67 to 96.66 per cent from one day to ten days after treatment, whereas significantly highest mortality occurred in chemical check malathion 5D @ $1 \%(100.00 \%)$ which was superior over all treatments and there was no mortality in control as seen in table 1 and figure 3 .

Effectiveness of green zinc oxide nanoparticles may be attributed to the damage to the protective wax coat on the cuticle of insects, both by sorption and abrasion so that the insects begin to lose water and die due to desiccation (Arumugam et al., 2015).

These findings are in agreement with those of Abo Arab et al., (2014) who reported that malathion increased mortality and reduced the number of progeny of $S$. oryzae or S. zeamais compared to nanoparticles (Al2O3-ZnO) and control. Kirthi et al., (2011) reported that the comparison between acaricidal, licicidal and larvicidal activities of zinc oxides and the synthesized $\mathrm{ZnO}$ nanoparticles, the mortality effect of $\mathrm{ZnO}$ nanoparticles was significant Malaikozhundun and Vinodhini (2017) reported that the treatment with $\mathrm{Pp}-\mathrm{ZnO} \mathrm{NPs}$ at $25 \mu \mathrm{g} \mathrm{mL}-1$ increased the mortality of $C$. maculatus to $100 \%$, similarly Rouhani et al., (2012a) reported efficiency of silver and Zinc nanoparticles at $20 \mathrm{mg} / \mathrm{l}$ in Aphis nerii, and Salem et al., (2015) for aluminium and Zinc oxide nanoparticles at $2 \mathrm{~g} / \mathrm{kg}$ in $T$. castaneum.

\section{Oviposition of Callasobruchus analis}

Efficacy of zinc oxide nanoparticles on egg laying by $C$. analis on chick pea seeds (Variety JG-11) revealed (Table 2) that the number of eggs laid per 100 seeds were nil in the malathion treatment after 30days as compared to the treatment with zinc oxide nanoparticles@1500ppm concentration with 2.66 eggs per 100 seeds, and @ 1250 ppm concentration with 6.33 eggs per 100 seeds. However, the maximum number of eggs was recorded in untreated check $\left(\mathrm{T}_{9}\right)(65.00$ eggs / 100 seeds).

Table.1 Effect of zinc oxide green nanoparticles on pulse beetle in chick pea seeds

\begin{tabular}{|c|c|c|c|c|c|}
\hline \multirow[t]{2}{*}{ Treatment details } & \multicolumn{5}{|c|}{ Mortality of pulse beetle (\%) } \\
\hline & 1 DAT & 3 DAT & 5 DAT & 7 DAT & 10 DAT \\
\hline $\begin{array}{l}\text { T1: Green zinc oxide nanoparticle } \\
\text { @125 ppm }\end{array}$ & $\begin{array}{c}6.67 \\
(12.39)^{f}\end{array}$ & $\begin{array}{c}13.33 \\
(21.48)^{\mathrm{f}}\end{array}$ & $\begin{array}{c}16.66 \\
(23.86)^{\mathrm{e}}\end{array}$ & $\begin{array}{c}43.33 \\
(41.15)^{d}\end{array}$ & $\begin{array}{c}66.66 \\
(54.78)^{e}\end{array}$ \\
\hline $\begin{array}{l}\text { T2: Green zinc oxide nanoparticle } \\
\text { @ } 250 \text { ppm }\end{array}$ & $\begin{array}{c}13.33 \\
(21.14)^{\mathrm{e}}\end{array}$ & $\begin{array}{c}20.00 \\
(26.57)^{\mathrm{e}}\end{array}$ & $\begin{array}{c}26.66 \\
(31.00)^{\mathrm{e}}\end{array}$ & $\begin{array}{c}53.33 \\
(46.92) d\end{array}$ & $\begin{array}{c}76.66 \\
(61.55)^{\mathrm{cd}}\end{array}$ \\
\hline $\begin{array}{l}\text { T3:Green zinc oxide nanoparticle } \\
\text { @500 ppm }\end{array}$ & $\begin{array}{c}16.67 \\
(23.86)^{\mathrm{de}}\end{array}$ & $\begin{array}{c}33.33 \\
(34.88)^{\mathrm{d}}\end{array}$ & $\begin{array}{c}43.33 \\
(41.15)^{d}\end{array}$ & $\begin{array}{c}66.66 \\
(54.78)^{\mathrm{c}}\end{array}$ & $\begin{array}{c}83.33 \\
(66.81)^{\mathrm{c}}\end{array}$ \\
\hline $\begin{array}{l}\text { T4:Green zinc oxide nanoparticle } \\
\text { @750 ppm }\end{array}$ & $\begin{array}{l}20.00 \\
(26.57)^{\text {de }}\end{array}$ & $\begin{array}{c}36.33 \\
(37.22)^{\mathrm{cd}}\end{array}$ & $\begin{array}{c}56.66 \\
(48.85)^{\mathrm{c}}\end{array}$ & $\begin{array}{c}73.33 \\
(59.34)^{\mathrm{c}}\end{array}$ & $\begin{array}{c}86.66 \\
(68.86)^{\mathrm{c}}\end{array}$ \\
\hline $\begin{array}{l}\text { T5: Green zinc oxide nanoparticle } \\
\text { @ } 1000 \text { ppm }\end{array}$ & $\begin{array}{c}26.67 \\
(31.00)^{\mathrm{cd}}\end{array}$ & $\begin{array}{c}43.33 \\
(42.49)^{\mathrm{c}}\end{array}$ & $\begin{array}{c}66.66 \\
(54.78)^{\mathrm{c}}\end{array}$ & $\begin{array}{c}76.66 \\
(61.89)^{\mathrm{c}}\end{array}$ & $\begin{array}{c}93.33 \\
(77.71)^{b}\end{array}$ \\
\hline $\begin{array}{l}\text { T6: Green zinc oxide nanoparticle } \\
\text { @ } 1250 \text { ppm }\end{array}$ & $\begin{array}{c}36.67 \\
(37.22)^{\mathrm{bc}}\end{array}$ & $\begin{array}{c}70.00 \\
(57.33)^{b}\end{array}$ & $\begin{array}{l}80.00 \\
(63.93)^{b}\end{array}$ & $\begin{array}{c}90.00 \\
(71.57)^{b}\end{array}$ & $\begin{array}{c}96.66 \\
(83.52)^{\mathrm{ab}}\end{array}$ \\
\hline $\begin{array}{l}\text { T7: Green zinc oxide nanoparticle } \\
\text { @1500 ppm }\end{array}$ & $\begin{array}{c}40.00 \\
(39.15)^{b}\end{array}$ & $\begin{array}{c}76.66 \\
(61.22)^{b}\end{array}$ & $\begin{array}{c}83.33 \\
(66.14)^{b}\end{array}$ & $\begin{array}{c}93.33 \\
(77.71)^{\mathrm{b}}\end{array}$ & $\begin{array}{c}100.00 \\
(90.00)^{\mathrm{a}}\end{array}$ \\
\hline T8: Malathion 5D @1 \% & $\begin{array}{c}66.67 \\
(54.12)^{\mathrm{a}}\end{array}$ & $\begin{array}{c}90.0 \\
(71.57)^{\mathrm{a}}\end{array}$ & $\begin{array}{c}96.66 \\
(83.52)^{\mathrm{a}}\end{array}$ & $\begin{array}{l}100.00 \\
(90.00)^{\mathrm{a}}\end{array}$ & $\begin{array}{c}100.00 \\
(90.00)^{\mathrm{a}}\end{array}$ \\
\hline T9: Untreated control & $\begin{array}{c}0.00 \\
(0.00)^{\mathrm{g}}\end{array}$ & $\begin{array}{c}0.00 \\
(0.00)^{\mathrm{g}}\end{array}$ & $\begin{array}{c}0.00 \\
(0.00)^{\mathrm{f}}\end{array}$ & $\begin{array}{c}0.00 \\
(0.00)^{\mathrm{e}}\end{array}$ & $\begin{array}{c}0.00 \\
(0.00)^{\mathrm{f}}\end{array}$ \\
\hline S.Em \pm & 0.31 & 0.28 & 0.34 & 0.36 & 0.32 \\
\hline CD@1\% & 1.26 & 1.14 & 1.38 & 1.47 & 1.29 \\
\hline
\end{tabular}

DAT: Days after treatment; Figures in the parentheses are angular transformed values.

Figures in the column followed by same letters are not-significant at $\mathrm{p}=0.01$ by DMRT 
Table.2 Effect of zinc oxide green nanoparticle on pulse beetle in chick pea seeds

\begin{tabular}{|c|c|c|c|c|c|c|c|}
\hline \multirow[t]{2}{*}{ Treatment details } & \multicolumn{4}{|c|}{30 Days after treatment } & \multirow{2}{*}{$\begin{array}{c}\text { Germination } \\
(\%)\end{array}$} & \multirow{2}{*}{$\begin{array}{l}\text { Dehydrogena } \\
\text { se enzyme } \\
\text { activity (OD } \\
\text { value) }\end{array}$} & \multirow{2}{*}{$\begin{array}{l}\text { Per cent } \\
\text { reduction } \\
\text { over } \\
\text { control }\end{array}$} \\
\hline & $\begin{array}{c}\text { Number of } \\
\text { eggs/100 } \\
\text { seed }\end{array}$ & $\begin{array}{l}\text { Number of } \\
\text { adults } \\
\text { emerged } \\
\text { /100g seeds }\end{array}$ & $\begin{array}{c}\text { Seed damage } \\
(\%)\end{array}$ & $\begin{array}{l}\text { Seed weight } \\
\text { loss }(\%)\end{array}$ & & & \\
\hline $\begin{array}{l}T_{1} \text { : Green zinc oxide } \\
\text { nanoparticle @125 ppm }\end{array}$ & $\begin{array}{l}31.33^{*} \\
(5.64)^{\mathrm{b}}\end{array}$ & $\begin{array}{l}15.00^{*} \\
(3.94)^{\mathrm{b}}\end{array}$ & $\begin{array}{l}11.33^{* *} \\
(19.67)^{\mathrm{b}}\end{array}$ & $\begin{array}{l}2.66^{* *} \\
(9.36)^{b}\end{array}$ & $\begin{array}{c}90.17 \\
(72.38)\end{array}$ & 1.997 & 26.10 \\
\hline $\begin{array}{l}T_{2}: \text { Green zinc oxide } \\
\text { nanoparticle @ } 250 \text { ppm }\end{array}$ & $\begin{array}{c}27.00 \\
(5.24)^{c}\end{array}$ & $\begin{array}{c}12.66 \\
(3.63)^{\mathrm{c}}\end{array}$ & $\begin{array}{c}9.33 \\
(17.78)^{\mathrm{c}}\end{array}$ & $\begin{array}{c}2.33 \\
(8.74)^{b}\end{array}$ & $\begin{array}{c}91.00 \\
(73.05)\end{array}$ & 2.013 & 35.26 \\
\hline $\begin{array}{l}T_{3} \text { : Green zinc oxide } \\
\text { nanoparticle @ 500 ppm }\end{array}$ & $\begin{array}{l}21.33 \\
(4.67)^{d}\end{array}$ & $\begin{array}{l}11.00 \\
(3.39)^{\mathrm{d}}\end{array}$ & $\begin{array}{c}7.66 \\
(16.07)^{d}\end{array}$ & $\begin{array}{c}2.00 \\
(8.13)^{\mathrm{bc}}\end{array}$ & $\begin{array}{c}92.33 \\
(73.93)\end{array}$ & 2.019 & 44.25 \\
\hline $\begin{array}{l}T_{4} \text { : Green zinc oxide } \\
\text { nanoparticle @750 ppm }\end{array}$ & $\begin{array}{c}18.66 \\
(4.38)^{\mathrm{e}}\end{array}$ & $\begin{array}{c}9.33 \\
(3.13)^{\mathrm{e}}\end{array}$ & $\begin{array}{c}4.66 \\
(12.46)^{\mathrm{e}}\end{array}$ & $\begin{array}{c}1.66 \\
(7.37)^{\mathrm{cd}}\end{array}$ & $\begin{array}{c}93.17 \\
(75.04)\end{array}$ & 2.106 & 53.87 \\
\hline $\begin{array}{l}T_{5}: \text { Green zinc oxide } \\
\text { nanoparticle @ } 1000 \text { ppm }\end{array}$ & $\begin{array}{l}12.66 \\
(3.63)^{f}\end{array}$ & $\begin{array}{c}5.66 \\
(2.48)^{\mathrm{f}}\end{array}$ & $\begin{array}{c}3.66 \\
(11.02)^{\mathrm{f}}\end{array}$ & $\begin{array}{c}1.33 \\
(6.54)^{\mathrm{de}}\end{array}$ & $\begin{array}{c}94.33 \\
(76.23)\end{array}$ & 2.111 & 63.03 \\
\hline $\begin{array}{l}T_{6}: \text { Green zinc oxide } \\
\text { nanoparticle @ } 1250 \text { ppm }\end{array}$ & $\begin{array}{c}6.33 \\
(2.60)^{\mathrm{g}}\end{array}$ & $\begin{array}{c}3.33 \\
(1.95)^{\mathrm{g}}\end{array}$ & $\begin{array}{c}1.66 \\
(7.33)^{\mathrm{g}}\end{array}$ & $\begin{array}{c}1.00 \\
(5.74)^{\mathrm{e}}\end{array}$ & $\begin{array}{c}94.83 \\
(76.86)\end{array}$ & 2.128 & 72.02 \\
\hline $\begin{array}{l}\mathrm{T}_{7} \text { : Green zinc oxide } \\
\text { nanoparticle @ } 1500 \text { ppm }\end{array}$ & $\begin{array}{c}2.66 \\
(1.77) \mathrm{h}\end{array}$ & $\begin{array}{c}0.66 \\
(1.05) \mathrm{h}\end{array}$ & $\begin{array}{c}0.33 \\
(1.91) \mathrm{h}\end{array}$ & $\begin{array}{l}0.00 \\
(0.00) f\end{array}$ & $\begin{array}{c}95.33 \\
(77.53)\end{array}$ & 2.143 & 100 \\
\hline $\mathrm{T}_{8}$ : Malathion 5D @1\% & $\begin{array}{c}0.00 \\
(0.71)^{\mathrm{i}}\end{array}$ & $\begin{array}{c}0.00 \\
(0.71)^{\mathrm{i}}\end{array}$ & $\begin{array}{c}0.00 \\
(0.00)^{\mathrm{h}}\end{array}$ & $\begin{array}{c}0.00 \\
(0.00)^{\mathrm{f}}\end{array}$ & $\begin{array}{c}91.67 \\
(73.22)\end{array}$ & 2.102 & - \\
\hline T9:Untreated control & $\begin{array}{c}65.00 \\
(8.09)^{\mathrm{a}}\end{array}$ & $\begin{array}{l}52.66 \\
(7.29)^{\mathrm{a}}\end{array}$ & $\begin{array}{c}14.66 \\
(22.52)^{\mathrm{a}}\end{array}$ & $\begin{array}{c}3.6 \\
(11.02)^{\mathrm{a}}\end{array}$ & $\begin{array}{c}89.67 \\
(71.25)\end{array}$ & 2.035 & - \\
\hline S.Em \pm & 0.07 & 0.08 & 0.32 & 0.18 & 0.18 & 0.001 & - \\
\hline CD@1\% & 0.29 & 0.33 & 1.31 & 0.72 & 0.73 & 0.005 & \\
\hline
\end{tabular}

* Figures in the parentheses are $\sqrt{ }(\mathrm{x}+1)$ transformed values,

** Figures in the parentheses are angular transformed values.

Figures in the column followed by same letters are not-significant at $\mathrm{p}=0.01$ by DMRT 
Fig.1 UV - Visible spectrum analysis of biosynthesized zinc oxide nanoparticles

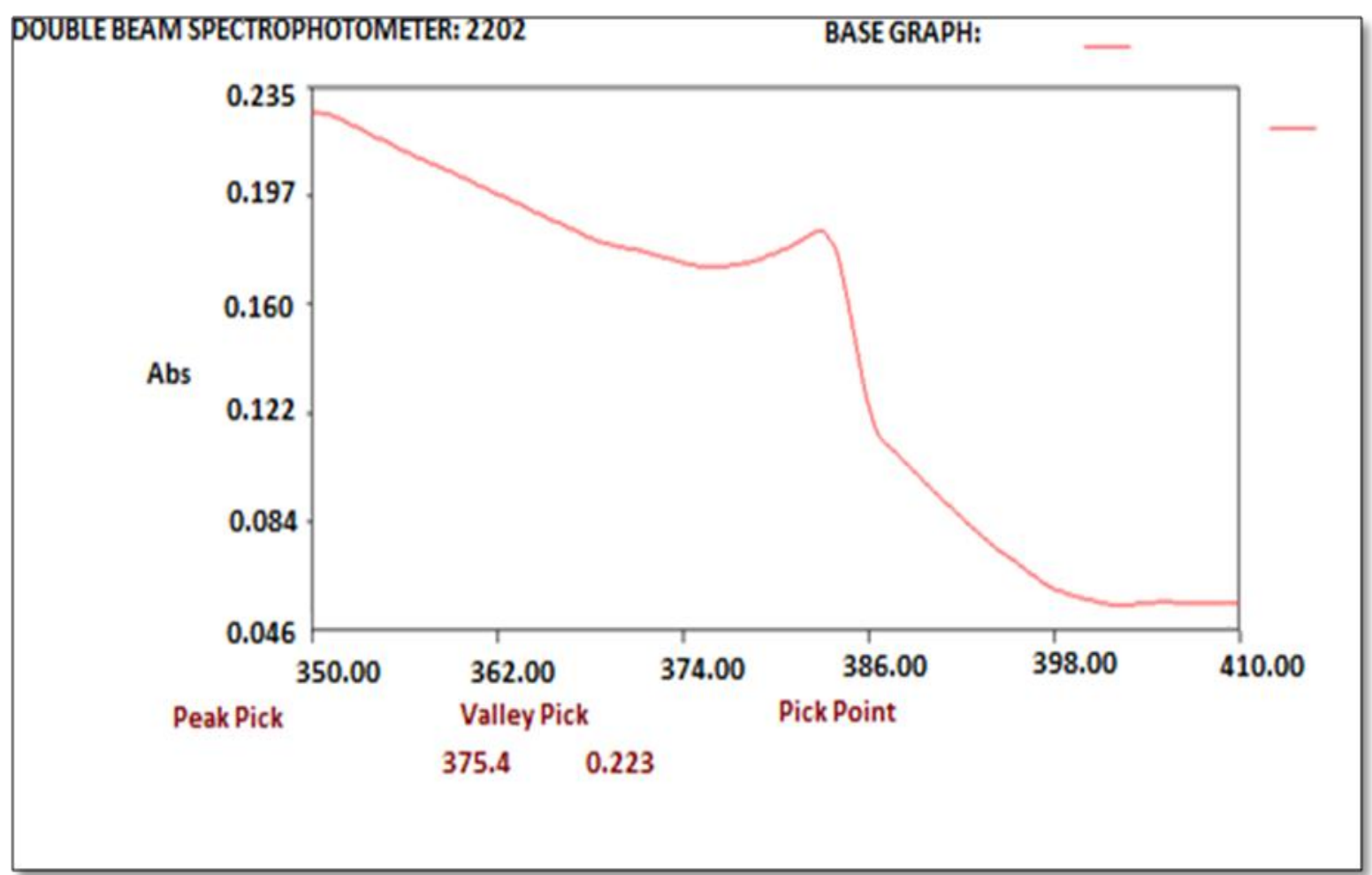

Fig.2 Average particle daimeter of zinc oxide green nanaoparticle

Results

$\begin{array}{rlllll} & & & \text { Size (d.n... } & \text { \% Intensity: } & \text { St Dev (d.n... } \\ \text { Z-Average (d.nm): } & 20.67 & \text { Peak 1: } & 90.51 & 78.9 & 32.97 \\ \text { Pdl: } & 1.000 & \text { Peak 2: } & 1.618 & 21.1 & 0.3610 \\ \text { Intercept: } & 0.338 & \text { Peak 3: } & 0.000 & 0.0 & 0.000 \\ \text { Result quality } & \text { Refer to quality report } & & & \end{array}$

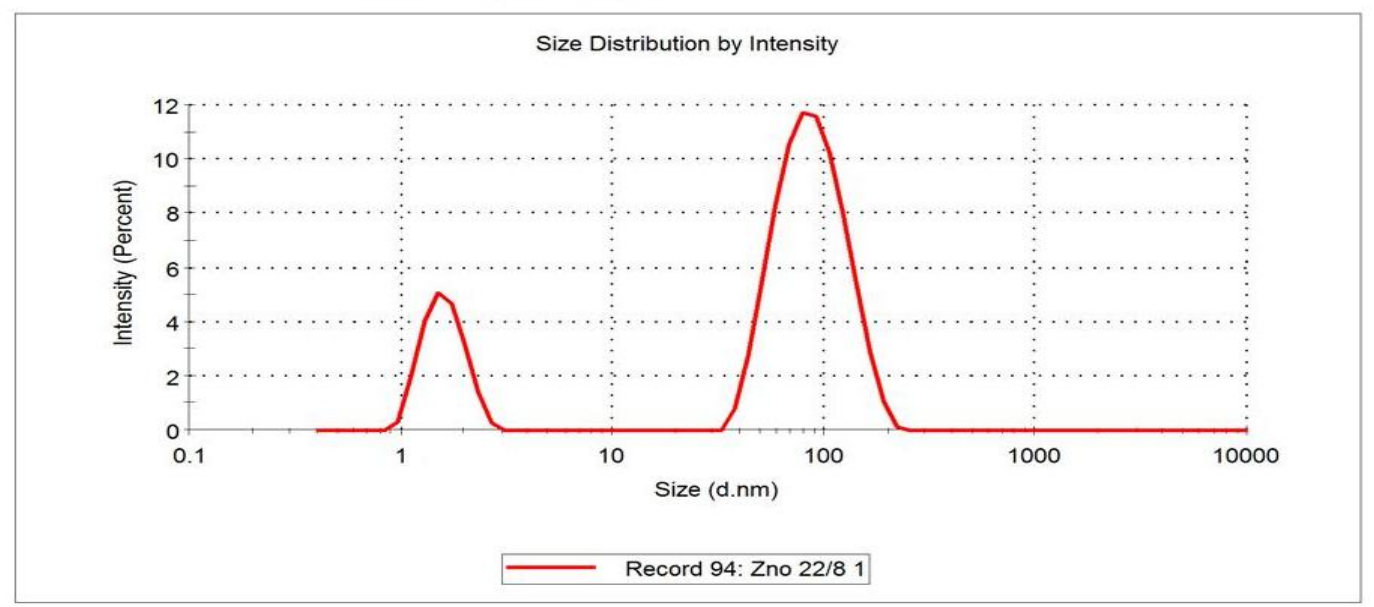


Fig.3 Effect of zinc oxide green nanoparticles on pulse beetle

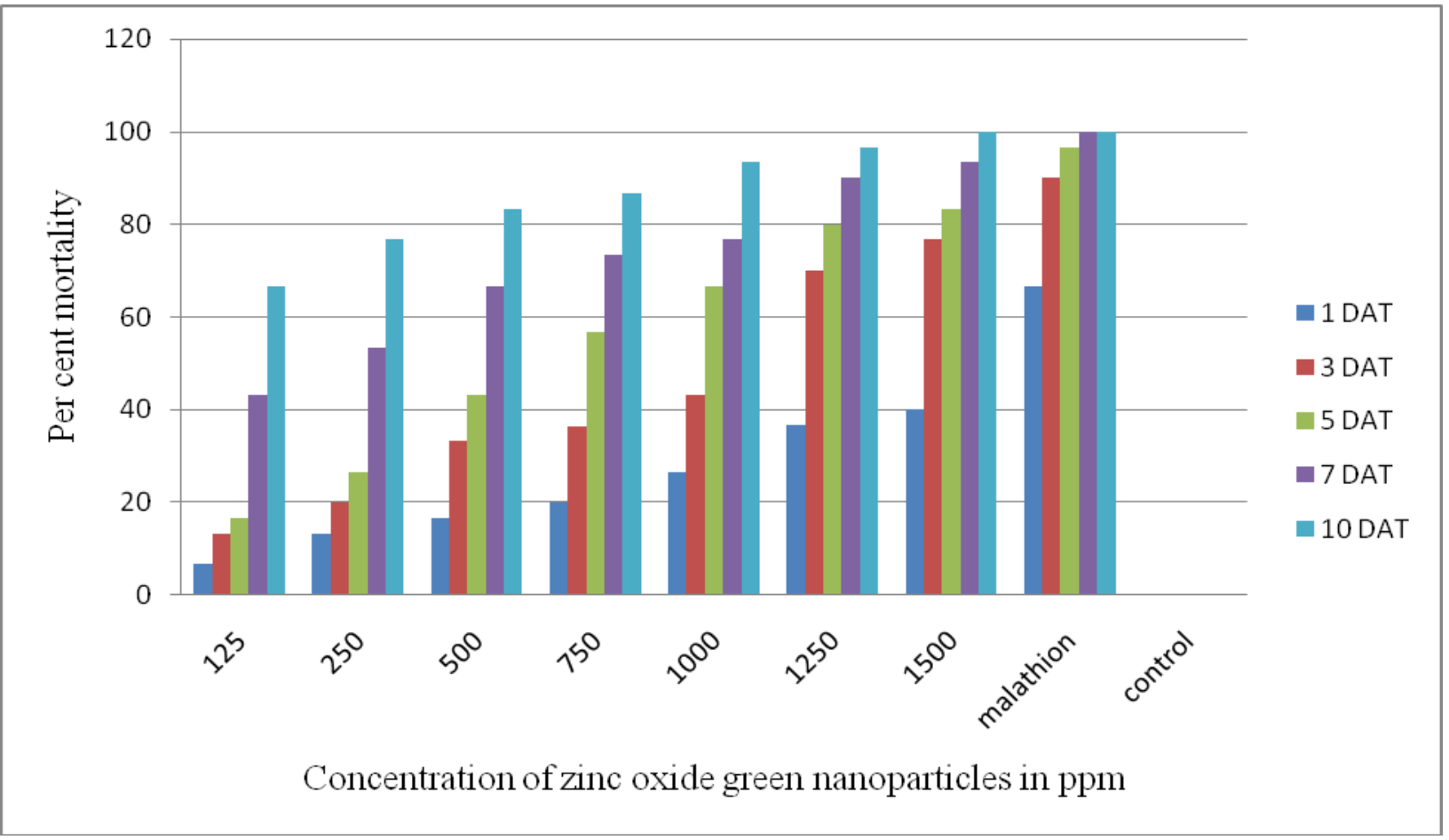

Fig.4 Effect of zinc oxide nanoparticles on quality parameters of chick pea seeds

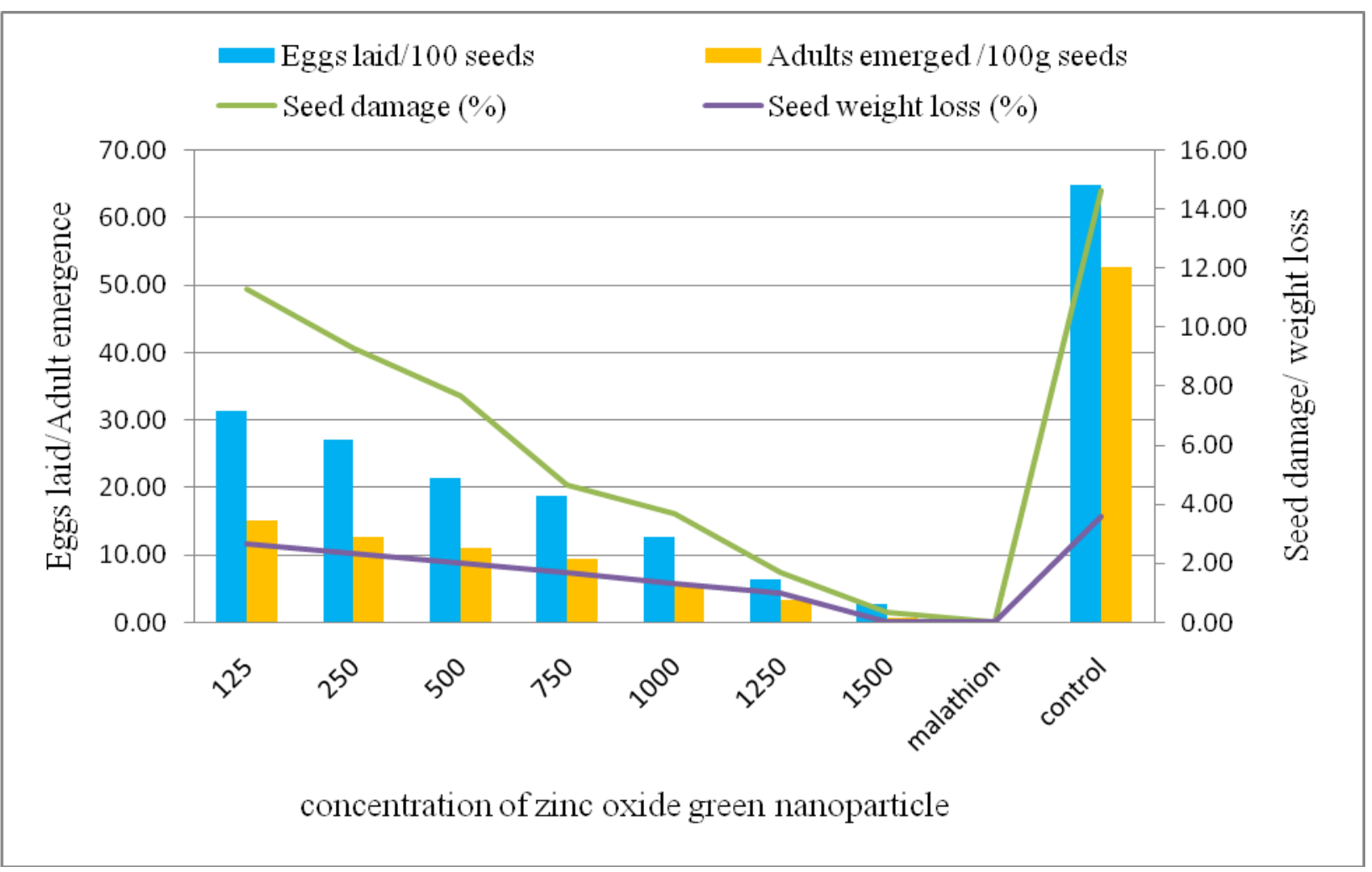




\section{Population buildup of Callasobruchus analis}

The adult population builds up after 30 days of storage ranged from 0.00 to 52.66 adults per $100 \mathrm{~g}$ of seeds (Table 2). There was no adult population recorded on chick pea seeds treated with Malathion 5D @ 1\%. This treatment was followed by zinc oxide nanoparticle @ 1500 ppm (0.66 adults /100 g of seeds) which proved to be superior over other treatments, followed by zinc oxide nanoparticle at $1250 \mathrm{ppm}$ concentration (3.33 adults / $100 \mathrm{~g}$ of seeds) and at 1000ppm concentration (9.33 adults / $100 \mathrm{~g}$ of seeds). However, the highest adult population build up was noticed in untreated check $\left(\mathrm{T}_{9}\right)(52.66$ adults / $100 \mathrm{~g}$ seeds) after 30 days of treatment.

\section{Seed damage by Callasobruchus analis}

From results depicted in table 2 it was evident that there was no seed damage noticed in Malathion 5D @ 1\% treated seeds and lowest in zinc oxide nanoparticle $\left(\mathrm{T}_{7}\right) @ 1500 \mathrm{ppm}$ concentration $(0.33 \%)$ followed by zinc oxide nanoparticle $\left(\mathrm{T}_{6}\right) @ 1250$ ppm concentration (1.66\%) and @ 1000ppm concentration $(3.66 \%)$. Whereas, significantly highest seed damage was recorded in untreated check (14.66\%). Highest seed germination (95.33\%) and dehydrogenase enzyme activity (2.143) was noticed in zinc oxide nanoparticle @ 1500ppm proving that it did not exhibit any adverse effect on quality of seeds.

\section{Seed weight loss due to Callasobruchus analis}

The seed weight loss due to infestation by pulse beetle on chick pea seeds recorded on $30^{\text {th }}$ day after release (Table 2) of pulse beetle indicated that the malathion 5D @ $1 \%$ and zinc oxide green nanoparticle $\left(\mathrm{T}_{7}\right) @ 1500$ ppm, proved to be significantly superior over all other treatments with no seed weight loss. The untreated check recorded 3.66 per cent loss in seed weight on 30 days of imposing treatments which was inferior to other treatments as seen in figure 4 .

Since there are no reviews available on zinc oxide green nanoparticles against adult mortality and persistence studies of $C$. analis, hence reviews of other nanoparticles on other insects are presented here. Arumurugan et al., (2015) noticed that fecundity, adult emergence, seed damage by pulse beetle was reduced when the seeds of gram treated with SNPs at $2 \mathrm{~g} / \mathrm{kg}$ of seeds. Sabour (2012) studied the persistence effect of silica gel Cab-O-Sil-750 and silica gel Cab-O-Sil-500 tested against $S$. oryzae under laboratory condition. The number of eggs laid/ female were significantly decreased to $6 \pm 1.0$ and $11 \pm 0.51$ as compared to $99.1 \pm 1.43$ and $97.2 \pm 1.82$ in the control and adult emergence was reduced to 91 and $90 \%$ after 100 and 120 days of stored condition respectively.

Zinc oxide green nanoparticles can be effectively used for the management of pulse beetle in chickpea which inhibited egg laying, emergence of adults, seed damage, increased mortality of adults and this can be used an alternate strategy to chemical control.

\section{References}

Abo-Arab, R. B. H. and Hashem. A. S., 2014, Comparative bioactivity of aluminum oxide $\left(\mathrm{Al}_{2} \mathrm{O}_{3}\right)$, titanium dioxide $\left(\mathrm{TiO}_{2}\right)$ nanoparticles and malathion on Sitophilus oryzae L. and Sitophilus zeamais (Motsch). Global J. Agric. Food Safety Sci., 1(2): 122-133

Amrita, R., Reena, S. L., Mohammad, J. and Kapil, L., 2015, Antibacterial activity of Zinc oxide nanoparticles prepared from 
Brassica oleraceae leaves extract. Int. J. Adv. Res., 3(11): 322-328.

Arumugam, G., Velayutham, V., Shanmugavel, S. and Sundaram, J., 2015, Efficacy of nanostructured silica as a stored pulse protector against the infestation of bruchid beetle, Callosobruchus maculates (Coleoptera: Bruchidae). Appl. Nanosci., 6(4): 445450

Awwad, A. M., Albiss, B. and Ahmad, A. L., 2014, Green synthesis, characterization and optical properties of Zinc oxide nanosheets using Olea europea leaf extract. Adv. Mat. Lett., 5(9): 520-524.

Chitra, S. and Subramanian, S., 2016, Storage insect pests and their damage symptoms: an overview. J. Gra. Sto. Res.50-57.

Gujar, G. T. and Yadav, T. D., 1978, feeding of Callosobruchus maculatus (Fab.) and Callosobruchus chinensis (Linn.) in green gram. Ind. J. Ent. 40: 108-112.

Jordan, W., 2010, Nanotechnology and pesticides. Pesticide Program Dialogue Committee, April29,2010.https://www. nanotechproject.org/process/assets/files/ 8309/epa_newpolicy_nanomaterials.pdf

Khot, L. R., Sankaran, S., Ehsani, R., and Schuster, E.W., 2012, Applications of nanomaterials in agricultural production and crop protection. A review. Crop Prot., 35: 64-70.

Kirthi, A. V. Rajakuma, S. Marimuthu, T. Santhoshkuma, C. Joyaseelan and K. velayutham., 2011. Acaricidal, pediculocidal and larvicidal activity of synthesized $\mathrm{ZnO}$ nanoparticles using wet chemical route against feeding parasites. Parasitol Research, 109(2): 461-472.

Kumar, R., Sharon, M. and Choudhary, A. K., 2010, Nanotechnology in agricultural diseases and food safety. Journal of Phytology, 2: 8392.
Malaikozhundan, B. and Vinodhini, 2017, Nanopesticidal effects of Pongamia pinnata leaf extract coated zinc oxide nanoparticle against the Pulse beetle, Callosobruchus maculatus. Materials Today Communications, 3028 (17): 2532-4828.

Noorjahan, C. M., Shahina, S. K. J., Deepika, T. and Rafiq, S., 2015, Green synthesis and characterization of Zinc oxide nanoparticles from Neem (Azadirachta indicia). Int. J. Sci. Eng. Technol. Res., 4(30): 5751-5753.

Resham, S. Khalid, M. and Kazi, A. G., 2015, Nanobiotechnology in Agricultural Development. In: Plant Omics: The Omics of Plant Science, Springer. 13: 683-698.

Rouhani, M., Samih, M. A. and Kalantari, S., 2012a, Insecticide effect of Silver and Zinc nanoparticles against Aphis nerii Boyer de fonscolombe (Hemiptera: Aphididae). Chilean. J. Agri. Res., 72(4): 590-594.

Sabbour, M., 2012, Entomotoxicity assay of two nanoparticle materials $\left(\mathrm{Al}_{2} \mathrm{O}_{3}\right.$ and $\mathrm{TiO}_{2}$ ) against sitophilus oryzae under laboratory and store conditions in Egypt. Journal of Novel Applied Sciences, 1(4):103-108.

Salem, A. A., Hamzah, A.M. and Nariman, M. E., 2015, Aluminum and Zinc oxides nanoparticles as a new method in controlling the red flour beetle, Tribolium castaneum (Herbest) compared to malathion insecticide. Int. J. Sci. Res. Agr. Sci., 2: 001-006.

Scott, N. and Chen, H., 2003, Nanoscale science and engineering for agriculture and food systems. National Planning Workshop. Washington, DC. November 18-19, 2003.

Sindhura, K. S., Prasad, K. V., Selvam, P. and Hussain, O. M., 2015, Biogenic synthesis of Zinc nanoparticles from Thevetia peruviana and influence on 
soil exo-enzyme activity and growth of peanut plants. Int. J. Appl. Pure Sci. Agr., 1(2): 19-32.

Singh, C. B. and Larson, V. P., 2016, Advanced Pulse Storage and Management in Pulse handbook. CommmodityIndia.com
Supraja, N., Prasad, T. N. V. K. V., Krishna, T. G. and David, E., 2015, Synthesis, characterization and evaluation of the antimicrobial efficacy of Boswellia ovalifoliolata stem bark-extractmediated Zinc oxide nanoparticles, Appl Nanosci., 6(4): 581-590.

\section{How to cite this article:}

Wazid, Sushila Nadagouda, A. Prabhuraj, R. Harishchanra Naik, N.M. Shakuntala and Sharanagouda, H. 2018. Effect of Biosynthesized Zinc Oxide Green Nanoparticles on Pulse Beetle, Callosobruchus analis (Coleoptera: Chrysomelidae). Int.J.Curr.Microbiol.App.Sci. 7(09): 503-512. doi: https://doi.org/10.20546/ijcmas.2018.709.060 